\title{
Xelo Candel, Mientras las nubes arden, Sevilla, Renacimiento, 2018, 84 pp.
}

\author{
Arcadio López Casanova \\ Universidad de Valencia, España
}

Después de unos años de fecundo silencio, Xelo Candel nos trae Mientras las nubes arden ${ }^{1}$, un muy destacado poemario que, entre tanta voz ecoica y tanto libro fungible, de usar y tirar, nos evidencia su madurez creadora (que, por fortuna, ha tenido ya merecidos reconocimientos) y a la poeta honda y verdadera que es.

Un libro que no es un mero conjunto de poemas, sino que se nos ofrece como un acabado macrotexto poético, esto es, como un todo, un cuerpo artístico sabiamente organizado, en el que nada falta ni sobra, nada es elemento muerto o vacío; bien al contrario, desde su diseño más externo a su más honda y escondida palabra, todo tiene -alcanza- valor significativo, pertinencia expresiva. Todo nos "dice" algo, que así debe ser -plena, perfecta- la obra de arte del lenguaje.

Y lo comprobamos desde su propio título o indicador paratextual, que nos lleva al final del poema primero ("pasajeros/ incendiados, dioses de un mismo cauce,/ mientras arden las nubes") y a la cita de Claudio Rodríguez del poema penúltimo (“Un día habrá en que llegue hasta la nube”).

Y es que esas "nubes" vienen a emblematizar, como símbolo de lo ascensional y celeste, nuestros más altos, vivificadores, sublimadores anhelos, y "arden" -el fuego o poder solar que las incendia- la luz y el calor que en nuestro corazón, en nuestro reino interior con pasión y fulgor de vida los sostiene.

En su perfecto diseño, el poemario se articula en cuatro partes numeradas con romanos y cada una con su título identificador. Y si atendemos a esos títulos -que para algo están-, descubrimos que, de hecho, el libro queda organizado en una tensa simetría opositiva, pues las partes primera/ segunda ("Ser silencio"/ "Ser noche”) se oponen a la tercera / cuarta ("Ser palabra” " Ser mañana”). Más todavía: esa tensión o contraste de -diríamos- negatividad vs positividad, todavía se intensifica con la relación cruzada de las partes impares ("silencio/ palabra") y de las pares ("noche/ mañana").

Pero aún hay más sorpresas en el diseño del poemario. Curiosamente, las partes de la negatividad primera/ segunda- tienen el mismo número de poemas [11]; las partes de la positividad -tercera/ cuartason recurrentes sobre el [12]. Y bien sabemos que los números -como los colores o las flores- tienen una virtualidad simbólica que viene dada o determinada por tradiciones religiosas, culturales, sociales, etc.

Pues bien, el [11] es número negativo (rompe, excede el denario) y viene entonces a emblematizar la lucha interior, la disonancia, el conflicto; por su parte, el [12] es el número del desarrollo cíclico espaciotemporal, número que marca una evolución, una transformación. Recordemos, pues, lo que el diseño del libro nos propone: dos bloques contrastivos, uno de negatividad organizado sobre el número [11] (lucha interior, conflicto) y otro de positividad, montado -éste- sobre el número [12], i.e., evolución, transformación.

Tan acabado diseño macrotextual nos orienta, además, hacia la estructura interior o de sentido. La repetición de "SER" en los títulos de las cuatro partes, nos debe hacer entender que este poemario de Xelo Candel es, con propiedad, un diario en el que dominantemente habla -y se realiza- el "yo lírico", que en ocasiones se desdobla, crea una imagen en el espejo y desarrolla así un distanciador monólogo autorreflexivo ("El huésped", "Milagro en la palabra"), y -otras veces- apostrofa a un "tú lírico".

Apunto a entenderlo -a leerlo, claro- como un diario, porque nos traslada, en ajustada secuencialización, el "relato" lírico de una travesía experiencial, existencial, en todo su tránsito (propia de una relación entre un "yo" y un "tú"). Y aquí se advertirá, precisamente, su ajuste con lo que el diseño nos apuntaba. 
En efecto, el bloque negativo, regido por el [ 11 ] de la disonancia y el conflicto, está modulado por una melodía de la lamentación, de modo que la dicción lírica del “yo" - un sujeto de la privación-queda atemperada por un temple anímico desolado, por una tonalidad de sentimiento oscura, de la privación, como expresan si espigamos a vuelo de verso- las palabras más significativas y recurrentes: verbos como "cierra", "desaparece", "precipita”, "borrarse”, “oculta”, “destruye”; sustantivos como "vacío”, “abismos”, “oscuridad”, “páramo”; o adjetivos tal "irreal", "confuso", "amargo", "incierto", "deshabitado", etc.

Pero ese temple anímico o tonalidad va cambiando ya en el segundo bloque, regido por el [12] -evolucióny transformación-, cuando al menos se atisba un tránsito hacia la ilusión o la espera esperanzada. Bastaría -para comprobarlo- ir a los títulos de los poemas y ver el realce -ahora- de "milagro", "celebración", "asombro", o la recurrencia de "luz", de "día”, de "aire". O el poder de algunos versos (que no necesitan comentario):

Cuando llegue el momento,

(...) acontecerá la luz que nos es negada.

Fuente: ("Cuando ese día llegue")

Que [la vida] nos sea propicia y nos conforte, que el deseo renazca infatigable.

Fuente: (“Oda”)

O -ya en el cierre-:

\author{
Luz (...) que en la mañana nos convoca \\ y el alma enciende.
}

Fuente: ("Tal vez un dia")

Este diario, pues, en su secuencialización, en su tránsito de la negatividad a la positividad (que se espera y que parece anunciarse) marca de hecho en el "yo lírico" -en ese sujeto de la privación- un simbólico "morir/ renacer" ("soy lo que ha muerto", dirá), esto es, el dejar -o liberarse- de una forma de vida (y su estado vivencial) para abrirse -despertar- a una transformación, a una evolución positiva, a otro ciclo vital (como, por cierto, señalaba ya simbólicamente el número [12] del diseño ).

Diario de una travesía existencial - subrayamos- que se abre bien significativamente con el poema "La luz o la nada" (con "o" identificativa, i.e., luz que es nada) y se va a cerrar, de hecho, con "Tal vez un día”, una ilusionada declaración (con la cita -ya citada- de Claudio Rodríguez): "Quizás, quizás un día (...) se obre por fin el milagro/ y la vida/ aguarde en su derroche sucesivo”. Luego, ya como final, vendrá una conclusiva (y reflexiva) "Paradoja de ser".

Libro espléndido, de madurez - como ya apuntábamos al principio- este nuevo poemario de Xelo Candel, acabado en su diseño, hondo y conmovedor en su estructura de sentido. Libro, además, fiel a su modo o dicción lírica, a su voz más personal, más auténtica, y que en el lector acierta a cumplir con la funciónedificativa -la que nos ayuda a construir e iluminar nuestra existencia-, propia de la mejor y más alta poesía.

\title{
Notas
}

1 Ed. Renacimiento, Col. Calle del Aire, 175, 2018. 